\title{
Climate Change, Catholic Social Teaching, and Human Rights
}

\author{
Richard W. Miller, Ph.D. \\ Department of Theology, Creighton University, Omaha, NE, USA \\ richardmiller@creighton.edu
}

\begin{abstract}
The development of human rights thinking in the United Nations and the Catholic Church has operated on a separate track from the development of thinking regarding environmental concerns. This paper traces this historical divergence and some factors contributing to this divergence. It argues that climate stability is the most pressing earth system problem and not only should not be neglected by human rights thinkers (as in Catholic circles) or actively resisted in human rights circles (as argued by a prominent academic human rights lawyer); rather, a stable climate system should be considered a basic human right.
\end{abstract}

\section{Keywords}

anthropocene - catholic social teaching - Christianity - climate change - ecology human rights

\section{Climate Change, Catholic Social Teaching, and Human Rights}

"Everything is destroyed, our lives are forever changed."

Please world, put down your toys and listen. Something historic and horrible has happened. An unprecedented barrage of the strongest and deadliest Atlantic hurricanes in recorded history.

1 Searles/Lathon, St. John residents desperate after Irma. 


\section{Hurricane Harvey \\ Hurricane Irma \\ Hurricane Maria \\ Take heed. Because it did not come out of nowhere. It came out of climate change. ${ }^{2}$}

These are just two voices in a world where several billion people are now subjected to the potentially deadly impacts of climate change. ${ }^{3}$ While "the world", according to Michelle Bachelet, the United Nations High Commissioner for Human Rights, "has never seen a threat to human rights of this scope", ${ }^{4}$ the development of human rights thinking in the United Nations and the Catholic Church has operated on a separate track from the development of thinking regarding environmental concerns. Since there is virtually no treatment of climate change and human rights within the Catholic tradition and only limited, though growing, treatment in wider human rights literature, this paper will briefly sketch this historical divergence and some factors contributing to this divergence. It will argue that this divergence and neglect to draw together the climate emergency with human rights thinking is problematic in light of the emergence over the past half century of earth systems science, which forces us to rethink common uses of the concept environment. This paper will argue that climate stability is the most pressing earth system problem and not only should not be neglected by human rights thinkers (as in Catholic circles) or actively resisted in human rights circles (as argued by a prominent academic human rights lawyer); rather, the paper will argue that a stable climate system should be considered a basic human right.

The English word dignity is derived from the Latin dignitas, meaning being worthy or deserving. Dignitas in Ancient Roman thought was not a quality that was attributed to all people. It was reserved for the distinguished few, over against the vulgar masses, because of birth, social and political standing, or as

2 Jones, Irma Was Here, p. viii.

3 Mora et al., Global Risk of Deadly Heat, p. 5o1: “[...] We identified a global threshold beyond which daily mean surface air temperature and relative humidity become deadly. Around $30 \%$ of the world's population is currently exposed to climatic conditions exceeding this deadly threshold for at least 20 days a year."

4 Agence France-Presse in Geneva, Climate Crisis. 
the reward for virtuous character. ${ }^{5}$ The 1948 Un Declaration of Human Rights (UDHR), however, begins with an affirmation of the inherent dignity of the human person and extends that dignity to all human beings maintaining the existence of "equal and inalienable rights of all members of the human family", which "is the foundation of freedom, justice, and peace in the world." ${ }^{\text {In }}$ light of religious, cultural, social, political pluralism the ultimate reason as to why human beings have rights and why some are universal was not addressed by the first Human Rights commission. ${ }^{7}$ Papal Encyclicals and Catholic thinkers "influenced some of the major drafters of the Universal Declaration"8 and the distinctive Catholic development of human rights, flowing from human dignity, with its fullest exposition in John XxIII's Pacem in Terris followed and paralleled the Un Declaration of Human Rights. Within a few years of the publication of Pacem in Terris, "the Catholic Church became one of the world's foremost proponents of human rights."

Pacem in Terris grounded these rights in human nature; "while the framework appears to be one of natural law, [...] Human nature, not nature is the touchstone. Conscience, rather than cosmic law, is the foundation of the moral order."10 The dignity of the human being is grounded in the belief that human beings are created in the image of God and more specifically Christian beliefs about the Incarnation, redemption, grace, and eschatology. "When, furthermore", as John the XXIII writes, "we consider man's personal dignity from the standpoint of divine revelation, inevitably our estimate of it is incomparably increased. Men have been ransomed by the blood of Jesus Christ. Grace has made them sons and friends of God, and heirs to eternal glory."11

The moral and ethical claims of human rights promulgated in the $1948 \mathrm{UN}$ Declaration of Human Rights laid the foundation for the subsequent various covenants and treaties. The legal authority of the rights laid out in the 1948 Universal Declaration of Human Rights (UDHR) were established in the 1966 International Covenant on Civil and Political Rights (ICCPR) and on Economic, Social, and Cultural Rights (ICESCR). Those countries who sign and ratify these international covenants, ICCPR and/or ICESCR, are bound by these treaties such that they have a responsibility to ensure that the human rights of their citizens are respected.

\footnotetext{
5 Donnelly, Universal Human Rights, p. 122.

$6 \quad$ Universal Declaration of Human Rights, p. 1.

7 Glendon, Foundation of Human Rights, p. 2.

8 Christiansen, Commentary on Pacem in Terris, p. 235.

9 Christiansen, Church Teaching, Public Advocacy, and Environmental Action, p. 977.

10 Christiansen, Church Teaching, Public Advocacy, and Environmental Action, p. 226.

11 John XXIII, Pacem in Terris, no. 10.
} 
The 1948 UDHR and the subsequent UN human rights treaties of 1966 were created before environmental protection became an international issue. Concerns for conservation of land, wilderness, pollution, and resource exhaustion preceded the UDHR of 1948, "but the audience was small and the practical results few."12 Environmentalism (broadly defined as seeking "peaceful coexistence with, rather than mastery of, nature"13) emerged as an international phenomenon in the 1970's in the wake of the publication of Rachel Carson's Silent Spring (1962) with its attack on the extensive use of pesticides. ${ }^{14}$ The public concern with the environment in the 1970's was primarily centred around pollution with climate change becoming an international public issue in the late 1980 's. Yet, climate as a scientific issue dated back to 1820 and by the time of the publication of the UDHR in 1948, it had been 90 years since John Tyndall demonstrated that carbon dioxide is a greenhouse gas (1859) and fifty years since the Swedish Nobel prize winning geochemist Svante Arrhenius calculated that carbon dioxide emissions from the burning of fossil fuels could significantly warm the planet (1896). Guy Callendar in the 1930's and a host of brilliant scientists (Gilbert Plass, Hans Suess, Roger Revelle) in the 195o's rekindled the concern for pumping large amounts of $\mathrm{CO}_{2}$ in the atmosphere. While this scientific work had not yet become an international concern, it was not relegated to scientific journals; rather, the dangers of increased $\mathrm{CO}_{2}$ into the atmosphere were communicated to important centres of global power. The distinguished physicist Edward Teller "warned them [petroleum industry leaders] of global temperature and sea-level rise by the end of the century."15 These scientific findings coupled with Charles David Keeling's measurements in the 1960s, showing the rise in atmospheric carbon dioxide levels, led to a number of high level scientific advisory panels that communicated the dangers of this rise in $\mathrm{CO}_{2}$ to Presidents Lyndon Johnson, Richard Nixon, and Jimmy Carter. ${ }^{16}$ President Johnson communicated these concerns in a special message to Congress in 1965. The head of the American Petroleum Institute (API), Frank Ikard, summarized the findings of President Johnson's Science Advisory committee at the 1966 API meeting by saying "the substance of the report is that there is still time to save the world's peoples from the catastrophic consequence of pollution, but time is running out." ${ }^{17}$

\footnotetext{
12 McNeill, Something New Under the Sun, K.L. [Kindle Location] 5068 of 8684.

13 McNeill, Something New Under the Sun, K.L. 5077 of 8684.

14 McNeill, Something New Under the Sun, K.L. 5080 of 8684.

15 Franta, Early Oil Industry Knowledge, p. 1025.

16 The history of the climate problem comes from the U.S. Senate Testimony of historian of science Naomi Oreskes, Senate Hearing Prepared Statement.

17 Franta, Early Oil Industry Knowledge, p. 1025.
} 
Despite the growing awareness of the pervasive risks to the human community of atmospheric greenhouse gas pollution, the field of human rights did not begin to engage the climate crisis until very recently. In 1979 the World Meteorological Organization in collaboration with the United Nations Educational, Scientific, and Cultural Organization (UnesCo), the United Nations Environment Programme (UNEP), the United Nations Food and Agriculture Organization (FAO), the World Health Organization (wHO), the International Council for Science (ICSU), convened in Geneva the World Climate Conference, which was attended by hundreds of specialists across a wide range of disciplines from dozens of countries. The declaration from that conference made "an appeal to all nations",

having regard to the all-pervading influence of climate on human society and on many fields of human activity and endeavor, the Conference finds that it is now urgently necessary for the nations of the world [...] to foresee and prevent potential man-made changes in climate that might be adverse to the well-being of humanity. [...] Food, water, energy, shelter, and health are aspects of human life that depend critically on climate. ${ }^{18}$

In light of these risks, the UN General Assembly endorsed the United Nations Environment Programme (UNEP) together with the World Meteorological Organization establishing the Intergovernmental Panel on Climate Change (IPCC) to provide policy makers regular assessments (published in 1990, 1995, 2001, 2007, 2015) of the state of climate science. These are some of the most peer reviewed documents in the history of science. ${ }^{19}$ While climate change has enormous implications for the human community and by extension human rights as indicated in the Geneva Conference in 1979, the United Nations only began to integrate human rights discourse through Human Rights Bodies and the United Nations Framework Convention on Climate Change (UNFCC) in $2007 .{ }^{20}$ Since this time more academic work, especially among international professors of law, has emerged. ${ }^{21}$

18 World Meteorological Organization, Proceedings of the World Climate Conference, p. 713.

19 See Brief/Clark, What Is the IPCC? and Feldman, Climate Scientists Defend IPCC Peer Review.

$20 \quad$ Akytpyis/Decaux/Leroy, Systemic Integration, p. 221.

21 See for example Humphreys, Human Rights and Climate Change and Quirico/Boumghar, Climate Change and Human Rights. 
In Catholic circles, while rights language can be traced back to the work of medieval jurists in the twelfth century 22 it was in John XXIII's Pacem in Terris (1963) that rights became fully integrated into Catholic social teaching. John Xxin's turn to human rights, contradicting Pope Pius IX's Syllabus of Errors (1864), became a way to advance human dignity in the context of the pluralism of a world church and an increasingly globalized interconnected world. The use of rights language to address environmental concerns has been very limited and to address climate change it has been non-existent. In his 199o World Day of Peace Message John Paul II argued for the right to a safe environment "as a right that must be included in an updated Charter of Human Rights." ${ }^{23} \mathrm{He}$ called for a new solidarity between developed and developing countries and maintained that "there is urgent need to find a solution to the treatment and disposal of toxic wastes." ${ }^{24}$ In 2009 Benedict XVI in his Encyclical Caritas in Veritate emphasized the right to food and water as universal rights that have "an important place within the pursuit of other rights beginning with the fundamental right to life." ${ }^{25}$ And, in his 2010 World Day of Peace Message Benedict gave an impassioned plea to overcome the indifference to ecological devastation and its "profound impact on the exercise of human rights, such as the right to life, food, health and development."26 Laudato $S i$ is the most important document of modern Catholic social teaching on ecological devastation and its impact on the human community, especially the poor; yet, it drew upon human rights discourse somewhat sparingly, using rights language twelve times, largely in general ways. In two instances, rights are linked to environmental issues, and in both cases the issue was the right to water. Pope Francis referred to 'access to safe drinkable water as a basic and universal human right' because "it is essential to human survival and, as such, is a condition for the exercise of other human rights." 27 This important notion of basic rights will be returned to later.

In Christian academic circles, a search of the ATLA religion database shows over 9, ooo entries for human rights since the 1948 Universal Declaration of Human Rights, but only four articles, book chapters, or meaningful selections (i.e. at least six pages) deal directly with environment and human rights, seven

22 For a brief history of this development see Christiansen, Commentary on Pacem in Terris, p. 233-236. For the medieval and early modern background see Tierney, The Idea of Natural Rights.

23 John Paul II, World Day of Peace, p. 3.

24 John Paul II, World Day of Peace, p. 3.

25 Benedict XVI, Caritas et Veritate, no. 27.

26 Benedict XVI, World Day of Peace Message, p. 2.

27 Francis, Laudato Si', no. 3 o. 
deal directly with ecology and human rights, and one article deals directly with the problem of climate change and human rights by the Anglican ethicist Michael Northcott in 1999. In a recent article (2019), one of the foremost interpreters of human rights in the English-speaking Catholic world, in the final section of a paper treating "urgent human rights challenges today" identified the rights of refugees and the rights of women as areas where "further development is happening or needed today."28 In terms of the rights of refugees David Hollenbach, identifies "conflicts based on ethnic or religious identity" as "among the most important threats to human rights today." ${ }^{29} \mathrm{He}$ perceptively identifies income inequality as exacerbating the plight of refugees; for, the cumulative hardships suffered by low income white citizens create conditions for demagogic leaders to exploit those sentiments through scapegoating refugees and migrants. In this context, he does not, however, mention environmental concerns or more specifically how impacts from climate change create conditions that lead to significant migrations of people now and into the future.

Outside of Christian, and more precisely Catholic, circles greater attention has been given to the application of human rights to environmental concerns. In recent years regional human rights bodies, like the African Charter on Human and Peoples' Rights, "recognizes the right of 'a[ll] peoples' [not individual persons] to a 'general satisfactory environment favorable to their development"30 while the African Women's convention provides further specification by arguing for the right "to live in a healthy and sustainable environment."31 The additional protocol to the 2012 American Convention on Human Rights maintains that "everyone shall have the right to live in a healthy environment and to have access to basic public services." 32 And "the States Parties shall promote the protection, preservation, and improvement of the environment." ${ }^{33}$ The recent development of the convergence of human rights and environmental concerns, however, is not without controversy. Hurst Hannum argues that the contemporary tendency to create new rights or widen the scope of existing

28 Hollenbach, Human Rights in Catholic Social Thought, p. 259.

29 Hollenbach, Human Rights in Catholic Social Thought, p. 263.

30 African Charter on Human and Peoples' Rights, as quoted in: Hannum, Rescuing Human Rights, p. 47.

31 African Charter on Human and Peoples' Rights, as quoted in: Hannum, Rescuing Human Rights, p. 47.

32 Additional Protocol to the American Convention on Human Rights in the Area of Economic, Social and Cultural Rights, as quoted in: Hannum, Rescuing Human Rights, p. 47 .

33 Additional Protocol to the American Convention on Human Rights in the Area of Economic, Social and Cultural Rights, as quoted in: Hannum, Rescuing Human Rights, p. 47. 
rights followed by trying to coerce countries to comply with these norms will set back the human rights movement. In his critique, he maintains that

most of the anodyne international initiatives on human rights and the environment do little to promote either cause and [...] succeed only in conflating internationally binding human rights norms with voluntary platitudes. $^{34}$

We see then a distinguished law professor in the United States arguing for the exclusion of environmental concerns from human rights now and into the future, while one of the leading interpreters of human rights and Catholic social teaching utterly neglect the significance of environmental degradation in reflecting on future challenges for the Catholic Church on the question of human rights.

\section{$3 \quad$ Why the Divergence?}

The climate and human rights spheres within the UN and beyond have been very late to converge for a host of reasons. First, climate change was treated within the natural sciences and when it was engaged within the social sciences, economics has been the dominant discipline. Second, "climate change negotiations have centred on consensus-driven welfare-based solutions, approaches that have historically thrived independently of, and in parallel with, the human rights register." 35 Third, in the 2oth century, the threat posed by climate change was understood in terms of future forecasts and the future character of climate forecasts "escapes the ordinary purview of human rights analysis." 36 This is still true in the 21st century as scientists make forecasts for different global emission scenarios; the difference, however, is that the earlier forecasts are coming true such that climate impacts are not a future possibility but a present reality. Fourth, while rights to life and property have strong legal protection under international law, the threat from climate change can only be attributed indirectly. It is not this particular state actor violating this person or these people's rights, but it is global emissions that have built up since the industrial revolution. Fifth, climate often affects social and economic rights, which are already difficult to enforce under international law. Sixth, in

34 Hannum, Rescuing Human Rights, p. 48.

35 Humphreys, Introduction. Human Rights and Climate Change, p. 4.

36 Humphreys, Introduction. Human Rights and Climate Change, p. 4. 
human rights law governments have the primary duty to protect their citizen's human rights. The government of the Maldives is not responsible for the loss of life, land, property, culture, and ultimately the island itself from sea level rise. While the citizens of the Maldives' rights are being violated, the cause is outside of their territory so making a human rights claim, under existing case law, is difficult. Seventh, climate change has been referred to as an emergency, notably by the Former Secretary General of the UN, Ban Ki-Moon (2007), ${ }^{37}$ by one of the world's leading climate scientists Jim Hansen (2008), ${ }^{38}$ with a host of other scientists following suite culminating in the recent published climate emergency statement of 11,000 climate scientists. ${ }^{39}$ International human rights treaties allow for the suspension of human rights in an emergency situation. Those working in the field of human rights would have reason to be concerned with language of climate emergency because it could "empower government, both nationally and internationally, at the expense of individuals."40 Eighth, the consensus driven and compromise that has informed the work of international climate negotiations does not fit easily into human rights conversations where the difficulty of adjudicating between different human rights is often present. Different rights (e.g. property rights) might bring one into conflict with climate policies. As such, those advancing climate policies might not see human rights as a tool in advancing the reduction of greenhouse gases.

The neglect of climate change and human rights in Catholic circles is part of the general neglect of environmental issues leading up to the publication of Pope Francis's Laudato Si'. Prior to the publication of Laudato Si', the statements in the central documents of modern Catholic social teaching dealing with the environment would fit in a few pages.

In his argument that extending rights or widening the scope of rights could hurt the human rights movement, Hurst Hannum maintains that "human rights must be distinguished from other worthy initiatives, such as the prosecution of international criminals, saving the environment, reducing poverty, making business more responsible, and preventing or ending violent

37 Lagorio, U.N.'s Ban Says Global Warming Is 'an Emergency'.

38 Kenrick, NASA Scientist Cites 'Global Warming Emergency'.

39 Ripple et al., World Scientists' Warning of a Climate Emergency.

40 Humphreys, Introduction. Human Rights and Climate Change, p. 6. 
conflict". ${ }^{41} \mathrm{He}$ maintains that the right to a clean, healthy, and sustainable environment is very difficult to define and introduces into the discussion a host of uncertainties. He quotes Dinah Shelton, "The substance of environmental rights involves evaluating ecological systems, determining the impacts that can be tolerated and what is needed to maintain and protect the natural base on which life depends". ${ }^{42}$ In her treatment of examples of environmental harms that have been brought to regional human rights courts, the examples are ones dealing with pollution from toxic chemicals involving citizens of a particular state. These are localized rights violations. ${ }^{43}$

Shelton indicates "the substance of environmental rights involves evaluating ecological systems"; yet current science maintains that we have moved from the problem of disrupting an ecosystem and the effects it has on nature and human populations to disrupting the whole earth system. We have moved from questions of a safe environment, often understood in local or regional terms, to questions of a "safe operating space for humanity" 44 in the context of transgressing planetary boundaries. We must now understand ourselves not simply as agents who can and do pollute the air, rivers, ocean, and land with toxic chemicals that disrupt ecosystems and in turn harm ourselves and our fellow human beings; rather we must understand ourselves as agents who can and are destabilizing planetary systems. It is for this reason that the International Commission on Stratigraphy is now going through a formal process of deciding whether human beings have pushed themselves out of the geological epoch in which civilization emerged and developed (i.e. the Holocene, where $\mathrm{CO}_{2}$ levels were at $28 \mathrm{oppm}$ ) to a new era (i.e. the Anthropocene). The concept Anthropocene is not primarily about the expansion of human impacts on the environment or upon ecosystems or human beings dominating the natural world, as it is sometime wrongly understood, rather, it is about human beings destabilizing the earth system such that the earth system, through interlinked processes, will move to a new state less hospitable to human life and civilization.

In 2009 the Planetary Boundaries framework was introduced by twenty-six leading scientists in a highly influential paper, "Planetary Boundaries: Exploring the Safe Operating Space for Humanity". 45 This framework has been employed

\footnotetext{
41 Hannum, Rescuing Human Rights, p. 4.

42 Hannum, Rescuing Human Rights, p. 48. See Shelton, Developing Substantive Environmental Rights, p. 129.

43 See Shelton, Developing Substantive Environmental Rights, p. 89-120.

44 Rockström et al., Planetary Boundaries, p. 1. Rockström et al., A the Safe Operating Space for Humanity, p. 472. Steffen et al., Planetary Boundaries, p. 1259855-1.

45 Rockström et al., Planetary Boundaries, p. 1.
} 
throughout the earth science community with an updated paper in $2015 .{ }^{46}$ The Planetary Boundaries Working Group identified nine interlinked "biophysical processes that regulate the stability of the Earth system." ${ }^{.47}$ According to Rockström et al., "Transgressing one or more planetary boundaries may be deleterious or even catastrophic due to the risk of crossing thresholds that will trigger non-linear, abrupt environmental change within continental- to planetary-scale systems." ${ }^{48}$ The nine interlinked biophysical processes are climate change, change in biosphere integrity (i.e. measured in terms of species extinction), stratospheric ozone depletion, ocean acidification (shift in ocean chemistry due to the ocean absorbing $\mathrm{CO}_{2}$ ), biogeochemical flows (nitrogen and phosphorus used in fertilizing), land system change, freshwater use, atmospheric aerosol loading (airborne fine particulate pollution), and introduction of novel entities (toxic chemicals, plastics, etc.). ${ }^{49}$ In this framework climate change and biosphere integrity are considered "core" boundaries that provide "the planetary-level overarching systems within which the other boundary processes operate" such that "large changes in the climate or in biosphere integrity would likely, on their own, push the Earth System out of the Holocene state."50

Climate change, the first boundary, is the most pressing boundary; for the human community must immediately initiate unprecedented reductions in greenhouse gas emissions to avoid locking in cascading impacts that will profoundly affect all of the other boundaries. The Holocene is the past 11,700 years of a relatively stable climate in which human civilization developed with its stable coastlines and relatively stable growing regions. There are a host of indicators that the destabilization of the Holocene era climate has begun. A few of these indicators will be developed to illuminate the human rights implications of climate change. Six glaciers on the West Antarctica ice sheet are now in a phase of unstoppable melt that will lead to a sea level rise of 1.2 meters ( 4 feet). This will inundate land that is currently home to 204 million people. ${ }^{51}$ This level of sea level rise ( 4 feet) also condemns much of the rice growing regions of Asia to destruction, including 50 percent of the rice fields in Bangladesh (home to 160 million people with projections of 250 million

46 Steffen et al., Planetary Boundaries, p. 1259855-1-1259855-10.

47 Steffen et al., Planetary Boundaries, p. 1259855-9.

48 Rockström et al., Planetary Boundaries, p. 1.

49 All of these boundaries are significant but the explication of them including the myriad ways they interact and amplify each other is beyond the scope of this paper.

$5^{\circ} \quad$ Steffen et al., Planetary Boundaries, p. 1259855-8.

$51 \mathrm{Kulp} /$ Strauss, New Elevation, p. 3. This calculation is based on the conclusion from this study that the land of 1.7 million habitants will be threatened per vertical centimetre of sea level rise. 
by 2050) and more than half of those in Vietnam (the world's second largest rice exporter). ${ }^{52}$ The unstoppable melt from West Antarctica will also "likely trigger the collapse of the rest of the West Antarctic ice sheet, which comes with a sea level rise of between three and five meters [ 10 feet in some locations and 16 feet in other locations]" ${ }^{\text {"53 }}$. While Rignot states conservatively that this collapse could take centuries, a recent study on ice mass loss on Antarctica shows that the melt rate on Antarctica, mostly from West Antarctica, has tripled over the past decade. ${ }^{54}$ While the rate of ice mass loss from the Greenland ice sheet is thirteen times greater in the period 2012-2017 than the period $1992-1997 .{ }^{55}$ It is too early to see if this trend will continue; yet, Dr. Jim Hansen has argued that three to four feet of sea level rise is possible, on our current path, around 2065 with 5 meters ( 16.5 feet) a possibility by the end of the century. ${ }^{56}$ Richard Alley, another leading climate scientist holds that 15 to 20 feet of sea level rise is possible this century. ${ }^{57}$ A five meter ( 16.5 feet) will lead to 850 million climate migrants, while a six meter ( ${ }^{2} 20$ feet) will lead to over a billion migrants. ${ }^{58}$ Coastal cities will be effected by storm surges far sooner than the full inundation of these cities. Saltwater incursions of groundwater and storm surges will start to put coastal inhabitants under siege long before 1.2 meters of sea level rise. Indeed, it is estimated that "over 800 million people living in more than 570 coastal cities will be at risk of coastal flooding from at least (0.5 m) of sea level rise." 59

The conditions for large scale movements of people, which create conditions for conflict, will not only occur from sea level rise, but also by a host of other factors, including drought. Drought will be arriving earlier than sea level rise. Indeed, the transition to a more arid climate in the US Southwest and northern Mexico might already be under way ${ }^{60}$ and as we continue on our present path there is an increasing likelihood of mega-droughts, ${ }^{61}$ the kind that led to the destruction of past civilizations. The drought in Darfur was a factor in creating conditions for the conflict in Darfur, which was cited as an example

52 Brown, Plan B 4.0, p. 7.

53 Rignot, Global Warming.

54 Shepherd et al., Mass Balance of the Antarctic Ice Sheet from 1992 to 2017.

55 Shepherd et al., Mass Balance of the Greenland Ice Sheet from 1992 to 2018, p. 3.

$5^{6}$ Hansen et al., Ice Melt, Sea Level Rise and Superstorms, figure 5, p. 3767.

57 Richard Alley, interview.

$5^{8} \mathrm{Kulp} /$ Strauss, New Elevation, p. 3. This calculation is based on the conclusion from this study that the land of 1.7 million habitants will be threatened per vertical centimeter of sea level rise.

59 Urban Climate Change Research Network, The Future We Don't Want, p. 47.

6o Seager et al., Model Projections.

61 Cook, Unprecedented 2ist Century Drought Risk. 
by David Hollenbach on the human rights challenges of refugees, that lead to nearly 300,000 deaths from malnutrition, disease, and conflict. The most intense drought in the history of Syria led to mass migrations of farmers into the cities contributing to the destabilizing of Syria, its descent into civil war, the migration of 5.6 million Syrians into Europe and neighbouring countries contributing to the rise of right-wing ultranationalist parties across Europe. ${ }^{62}$

Fresh water, which is understood as a basic human right by the UN and by Pope Francis in Laudato $\mathrm{Si}^{\prime},{ }^{3}$ is also threatened by climate change. On our current path, in 205 o when $\mathrm{CO}_{2}$ levels reach 560 ppm many of the world's mountain glaciers, which feed the rivers that provide the fresh water for half the world's population, will be substantially diminished or gone. This includes glaciers in the Hindu-Kush-Himalayan-Tibetan plateau, which will create water problems for hundreds of million to a billion people in Asia. ${ }^{64}$

Food, which is understood as a basic right (UNDHR, 1948, ICCPR, 1966), will decline precipitously. Corn and soy yields in the US, which currently produces $41 \%$ of the world's corn and $38 \%$ of the world's soybeans, could be consigned to a $30 \%$ to $46 \%$ decline by mid-century and a $63 \%$ to $82 \%$ decline by the end of the century. ${ }^{65}$ This study focuses only on temperature, but drought and extreme precipitation events will also negatively affect global food security.

The negative effects will escalate post 2100; indeed, "decisions occurring over the next decade or two could significantly influence the trajectory of the Earth System for tens to hundreds of thousands of years and potentially lead to conditions that resemble planetary states that were last seen several millions of years ago, conditions that would be inhospitable to current human societies and to many other contemporary species." 66

Hurst Hannum wants to rescue human rights from what he sees as the expansion of human rights, which he argues undermines human rights, and wants to focus on what is legally possible to enforce under existing human rights covenants. Here he cites for instance the "committee that oversees the Convention on the Elimination of All Forms of Discrimination against Women (CEDA)" and

\footnotetext{
62 Kelley et al., Climate Change.

$63 \mathrm{un}$, The Human Right to Water and Sanitation. Milestones; Francis, Laudato Si', no. 30, 185.

64 Xu et al., Black Soot and the Survival of Tibetan Glaciers, p. 22114.

65 Schlenker/Roberts, Nonlinear Temperature Effects, p. 15594.

66 Steffen et al., Trajectories, p. 8253.
} 
its concern with "the continuing prevalence of sex-role stereotypes and by the reintroduction of such symbols as a Mother's Day and a Mothers Award, which it sees as encouraging women's traditional roles." ${ }^{67}$ The securing of women's human rights is crucial going forward, as David Hollenbach argues in looking to the future of rights; yet this example along with other examples provided by Hannum raise questions about inflating the currency of human rights only to devalue it. Pope Benedict offers a similar critique of the proliferation of rights and its capacity to undermine the international order. In his Encyclical Caritas in Veritate, Benedict wrote,

Individual rights, when detached from a framework of duties which grants them their full meaning, can run wild, leading to an escalation of demands which is effectively unlimited and indiscriminate. An overemphasis on rights leads to a disregard for duties. Duties set a limit on rights because they point to the anthropological and ethical framework of which rights are a part, in this way ensuring that they do not become license. ${ }^{68}$

Without duties, the right to development and other rights have no limits and can lead to excesses. One's right to food and water, must be coupled with one's duty to work to obtain food and water and one's duty to ensure that others have adequate food and water. This duty curbs the excesses in the developed world in order to help those in the developing world realize their rights for clean water and food. Pairing rights with duties has been a distinctive feature of Catholic human rights thinking since the publication of the Catholic Charter of human rights, Pacem in Terris. ${ }^{69}$ Benedict XvI's emphasis that rights must be paired with duties is a necessary corrective to the overemphasis and escalation of rights, but it is not likely sufficient to curb the excesses of rights discourse that Hannum criticizes. The introduction and focus on basic and fundamental rights will likely be necessary to constrain the proliferation of rights discourse that Hannum thinks weakens the human rights regime. Benedict points to this notion of fundamental rights when he writes, "The right to food, like the right to water, has an important place within the pursuit of other rights, beginning with the fundamental right to life."70 This focus on fundamental rights is strengthened by Benedict's argument that fundamental rights "remain

\footnotetext{
67 Hannum, Rescuing Human Rights, p. 5.

68 Benedict XVI, Caritas et Veritate no. 43.

69 John XXII, Pacem in Terris, no. 28-37.

70 Benedict XvI, Caritas et Veritate, no. 27.
} 
unacknowledged and are violated in much of the world" as opposed to the demand for "alleged rights, arbitrary and non-essential". ${ }^{11}$ Here we see an appeal to a hierarchy of rights. In a similar vein, Pope Francis referred to 'access to safe drinkable water as a basic and universal human right' because "it is essential to human survival and, as such, is a condition for the exercise of other human rights".72

These treatments of fundamental rights and basic rights can be strengthened by looking to the work of the pioneering rights theorist Henry Shue, whose classic work on basic rights was pivotal "in the rise of human rights to the 'status of a lingua franca of global moral discourse"." 73 It will also aid in dealing with Hannum's concern with the inflation of rights discourse. Shue argued that to establish "a minimum threshold based in rights, as [sic] least as a matter of initial or immediate obligation, allowed a response to charges that global ethics involved moral burdens that were simply excessive." ${ }^{74}$ For Shue, "rights are basic [...] only if enjoyment of them is essential to the enjoyment of all other rights." ${ }^{.75}$ In his argument that physical security is a basic right, physical security is understood as being free from the threat of "murder, torture, mayhem, rape, or assault." ${ }^{76}$ In his treatment of subsistence as a basic right, Shue defines subsistence as "unpolluted air, unpolluted water, adequate food, adequate clothing, adequate shelter, and minimal preventive public health care." ${ }^{77}$ Benedict XVI in his emphasis on the right to food and water links it to "the fundamental right to life"78 and Pope Francis's understanding of safe drinkable water as a basic right functions in a similar way, though less developed than Shue's basic rights. The "fundamental right to life", however, is an underdetermined conception and must be further specified to avoid the "absurd claim" 79 that since death and serious illness frustrate the enjoyment of rights then all human beings have a right to be free of death and serious illness. The problem with this is that "many causes of death and illness are outside the control of society, and many deaths and illnesses are the result of very particular conjunctions of circumstances that general social policies cannot

\footnotetext{
71 Benedict XVI, Caritas et Veritate, no. 43.

72 Francis, Laudato Si, no. 3 o.

73 Moyn, Not Enough, p. 162. Imbedded quote is from Charles R. Beitz though without a cited reference.

74 Moyn, Not Enough, p. 169.

75 Shue, Basic Rights, p. 19.

76 Shue, Basic Rights, p. 20.

77 Shue, Basic Rights, p. 23.

78 Benedict XVI, Caritas et Veritate, no. 27.

79 Shue, Basic Rights, p. 25.
} 
control." ${ }^{80}$ It is not, however, "impractical to expect some level of social organization to protect the minimal cleanliness of air and water and to oversee the adequate production, or import, and the proper distribution of minimal food, clothing, shelter, and elementary health care. It is not impractical, in short, to expect effective management, when necessary, of the supplies of the essentials of life." ${ }^{\prime 1}$ Thus,

when death and serious illness could be prevented by different social policies regarding the essentials of life, the protection of any human right involves avoidance of fatal or debilitating deficiencies in these essential commodities. And this means fulfilling subsistence rights as basic rights. This is society's business because the problems are serious and general. This is a basic right because failure to deal with it would hinder the enjoyment of all other rights. ${ }^{82}$

Drawing upon Shue, I would like to suggest that a stable climate should be considered a basic right tied to physical security and subsistence. That stable climate involves stabilizing global temperatures between $1^{\circ}$ and $1.5^{\circ} \mathrm{C}$. On our current path, the world will likely warm around $4^{\circ} \mathrm{C}$ by $2100 .{ }^{83}$ If the 2015 Paris Agreement carbon reduction commitments are realized through 2030 and go no further in emissions reductions post $203 \mathrm{O}$, then $\mathrm{CO}_{2}$ levels will likely rise to $665 \mathrm{ppm}$ causing $3.3^{\circ} \mathrm{C}$ warming by $2100 .{ }^{84}$ The agreement is based on IPCC climate models that only incorporate fast feedbacks. When we take into account longer term feedbacks, carbon dioxide could have more than twice the effect on global temperatures leading to over $6^{\circ} \mathrm{C}$ of warming. ${ }^{85} \mathrm{~A}$ recent commentary, by some of the world's leading climate scientists, highlights the two IPCC special reports in 2018 that argued that we might already be in the range (i.e. $1^{\circ}$ to $2^{\circ} \mathrm{C}$ rise in temperatures above preindustrial averages) to initiate tipping points to push us into a warmer world. ${ }^{86}$ In another review paper, many of these same authors, argued that "currently, the Earth System is on a Hothouse Earth pathway driven by human emissions of greenhouse gases

\footnotetext{
8o Shue, Basic Rights, p. 25 .

81 Shue, Basic Rights, p. 25.

82 Shue, Basic Rights, p. 25.

83 IPCC, Summary for Policy Makers 2014, p. 11, figure SPM. 6; Climate Rapid Overview and Decision-support Simulator (C-ROADS).

84 C-ROADS.

85 Hansen et al., Target Atmospheric $\mathrm{CO}_{2}$, p. 217.

86 Lenton et al., Climate Tipping Points, p. 592.
} 
and biosphere degradation." 87 In addition, "even if the Paris Accord target of a $1.5^{\circ} \mathrm{C}$ to $2.0^{\circ} \mathrm{C}$ rise in temperature is met, we cannot exclude the risk that a cascade of feedbacks could push the Earth System irreversibly onto a "Hothouse Earth" pathway." 88 A "hothouse earth" is an earth that was last seen in the Mid-Miocene (15-17 million years ago) when temperatures were $4^{\circ}$ to $5^{\circ} \mathrm{C}$ warmer than preindustrial temperatures. ${ }^{89}$ The authors state, "If damaging tipping cascades can occur and a global tipping point cannot be ruled out, then this is an existential threat to civilization." ${ }^{90}$ What does this existential threat to civilization mean? It means the unspeakable mass death of human populations, not to mention the mass extinction of species. The United Nations projects that the population will "reach 8.6 billion in 2030, 9.8 billion in 2050 and 11.2 billion in 2100 ". ${ }^{91}$ At $4^{\circ}-5^{\circ} \mathrm{C}$ the carrying capacity of planet could be reduced to between a half a billion and a billion people. This is the view of two directors of leading climate institutes. Hans Joachim Schellnhuber, who is the director of the Potsdam Institute for Climate Impact Research in Germany has argued that at $5^{\circ} \mathrm{C}$ the planet could only carry around a billion people ${ }^{92}$ and Kevin Anderson, former Director of the Tyndall Centre for Climate Research in England maintained that at " $4 \mathrm{C},{ }_{5} \mathrm{C}$ or $6 \mathrm{C}$, you might have half a billion people surviving". ${ }^{93}$

For Shue physical security rights and subsistence rights are basic. It is important to recognize that "it is not enough that people merely happen to be secure or happen to be subsisting. They must have a right to security and a right to subsistence - the continued enjoyment of the security and the subsistence must be socially guaranteed." ${ }^{94}$ The $1^{\circ} \mathrm{C}$ (350 ppm) "safe operating space" of the Planetary Boundary's group is likely now in the rearview mirror. Likely the best we can do now is move onto an emergency footing to hold to $1.5^{\circ} \mathrm{C}$ world, which will be fraught with dangerous impacts that will threaten physical security and subsistence for millions of people, but will likely be stable and thus avoid the cascading tipping points of a $2^{\circ} \mathrm{C}$ world that could push the human community into a hothouse earth. A world stabilized at $1.5^{\circ} \mathrm{C}$ above preindustrial temperatures should be worked toward by governments as a guarantee.

\footnotetext{
$87 \quad$ Steffen et al., Trajectories, p. 8254 .

88 Steffen et al., Trajectories, p. 8254

89 Steffen et al., Trajectories, p. 8253, figure 1 and table $\mathrm{S}_{1}$ in the appendix.

$90 \quad$ Lenton et al., Climate Tipping Points, p. 595.

91 United Nations Department of Economic and Social Affairs, World Population.

92 Schellnhuber, The MAD Challenge, see also Kanter, Warming Could Cut Population to 1 Billion.

93 Fyall, Warming Will 'Wipe Out Billions'.

94 Shue, Basic Rights, p. 26.
} 
The recognition of the negative effects of a destabilized climate, in which impacts will escalate for hundreds to thousands of years, for all other human rights is beginning to surface. As we saw in the introduction, Michelle Bachelet, the United Nations High Commissioner for Human Rights, recently told the UN human rights council in Geneva, "the world has never seen a threat to human rights of this scope."95 While the failure to link climate change and human rights together is being remedied within the UN and the wider human rights literature, the Catholic Church and the Catholic theological community need to urgently address the human rights implications of climate change to help the human community respond to the "unprecedented challenge [...] to create a 'Stabilized Earth' pathway that steers the Earth System away from its current trajectory toward the threshold beyond which is Hothouse Earth (Fig. 2)" ${ }^{\prime 6}$ As I have argued, a stabilized climate at $1.5^{\circ} \mathrm{C}$ should become a basic right beyond which physical security and subsistence cannot be guaranteed.

\section{Biography}

Richard W. Miller, Ph.D., is professor of philosophical and systematic theology and professor of sustainability studies at Creighton University. His research interests include the Mystery of God, divine providence and human suffering, and the planetary emergency. He has published articles in the most prestigious English speaking journals of theology and he is a contributor to and editor of seven books including God, Creation, and Climate Change: A Catholic Response to the Environmental Crisis (Orbis, 2010), which won a 2011 Catholic Press Association of the United States and Canada book award in the faith and science category. He has been invited to speak around the world on the planetary emergency, including the United Nations Framework Convention on Climate Change Conference (COP 22, 2016).

\section{Bibliography}

Agence France-Presse in Geneva: "Climate Crisis Is Greatest ever Threat to Human Rights, UN Warns", in: The Guardian, og.09.2019.

95 Agence France-Presse in Geneva, Climate Crisis.

96 Lenton et al., Climate Tipping Points, p. 8254. 
Akytpyis, Spyridon/Decaux, Emmanuel/Leroy, Bronwen: "Systemic Integration between Climate Change and Human Rights at the United Nations", in: Quirico Ottavo/ Mouloud Boumghar (ed.): Climate Change and Human Rights. An International and Comparative Law Perspective. London/New York, NY: Routledge, 2016, p. 221-235.

Alley, Richard: "National Climate Seminar, Bard Center for Environmental Policy. Interview with Eban Goodstein", https://vimeo.com/292991175 (19.09.2018).

Benedict XVI: Caritas in Veritate. Vatican City: Libreria Editrice Vaticana, 2009.

Benedict XVI: World Day of Peace Message. If You Want to Cultivate Peace, Protect Creation. Vatican City: Libreria Editrice Vaticana, 2010.

Brief, Carbon/Clark, Duncan: "What is the IPCC?", in: The Guardian, o6.12.2011.

Brown, Lester R.: Plan B 4.o. Mobilizing to Save Civilization. New York, NY: W.W. Norton \& Company, 2009.

Christiansen, Drew: "Commentary on Pacem in Terris (Peace on Earth)", in: Kenneth Himes/Lisa Sowle Cahill/Charles E. Curran/David Hollenbach/David Shannon (ed.): Modern Catholic Social Teaching. Commentaries and Interpretations. Washington, D.C.: Georgetown University Press, 2005, p. 217-243.

Christiansen, Drew: "Church Teaching, Public Advocacy, and Environmental Action", in: Zygon 46 (4/2011), p. 977.

Clark, Meghan J.: The Vision of Catholic Social Thought. The Virtue of Solidarity and the Praxis of Human Rights. Minneapolis, MN: Fortress Press, 2014.

Climate Rapid Overview and Decision-support Simulator (C-ROADS): "Scoreboard", April 2017, https://www.climateinteractive.org/programs/scoreboard/ (date of last access: 13.01 .2020$)$.

Cook, Benjamin I./Ault, Toby R./Smerdon, Jason E: "Unprecedented 21st century drought risk in the American Southwest and Central Plains", in: Science Advances $1(1 / 2015)$, p. $1-7$.

Donnelly, Jack: Universal Human Rights in Theory and Practice. Ithaca, NY: Cornell University Press, 2013.

Feldman, Stacy: "Climate Scientists Defend IPCC Peer Review as Most Rigorous in History", in: Inside Climate News, 26.02.2010.

Francis [Pope]: Laudato Si.' On Care for Our Common Home. Vatican City: Libreria Editrice Vaticana, 2015 .

Franta, Benjamin: "Early Oil Industry Knowledge of $\mathrm{CO}_{2}$ and Global Warming", in: Nature Climate Change 8 (2018), p. 1024 et seq.

Fyall, Jenny: “Warming Will 'Wipe out Billions', in: Scotsman, 29.11.20o9.

Glendon, Mary Ann: "Foundation of Human Rights. The Unfinished Business", in: American Journal of Jurisprudence 44 (1999), p. 2.

Hannum, Hurst: Rescuing Human Rights. A Radically Moderate Approach. Cambridge: Cambridge University Press, 2019. 
Hansen, James/Sato, Makiko/Pushker, Kharecha et al.: "Target Atmospheric $\mathrm{CO}_{2}$. Where Should Humanity Aim?", in: Open Atmospheric Science Journal 2 (2008), p. $217-231$.

Hansen, Jame/Sato, Makiko/Hearty, Paul et al.: "Ice Melt, Sea Level Rise and Superstorms. Evidence from Paleoclimate Data, Climate Modeling, and Modern Observations that $2^{\circ} \mathrm{C}$ Global Warming Could Be Dangerous", in: Atmospheric Chemistry and Physics Discussions, 16 (2016), p. 3761-3812.

Hollenbach, David: Claims in Conflict. Retrieving and Renewing the Catholic Human Rights Tradition. New York, NY: Paulist Press, 1979.

Hollenbach, David: "Human Rights in Catholic Social Thought. A Living Tradition and Some Urgent Challenges Today", in: Irish Theological Quarterly 84 (3/2019), p. $259-267$.

Humphreys, Stephen (ed.): Human Rights and Climate Change. Cambridge: Cambridge University Press, 2010.

John Paul II, [Pope]: World Day of Peace Message. Peace with God the Creator, Peace with all of Creation. Vatican City: Libreria Editrice Vaticana, 1990.

John XXIII, [Pope]: Pacem in Terris. Vatican City: Libreria Editrice Vaticana, 1963.

Jones, Diandra: Irma Was Here. Surviving the Eye of History's Strongest Atlantic Hurricane. Independently Published, 2019.

Kanter, James: "Warming Could Cut Population to 1 Billion", in: New York Times, 13.03.2009.

Kelley, Colin P./Mohtadi, Shahrzad/Cane, Mark A. et al.: "Climate Change in the Fertile Crescent and Implications of the Recent Syrian Drought", in: Proceedings of the National Academy of Sciences of the United States of America 112 (11/2015), p. 3241-3246.

Kenrick, Chris: "NASA Scientist Cites 'Global Warming Emergency", in: Palo Alto Online, 22.11.2008.

Kulp, Scott A./Strauss, Benjamin H.: "New Elevation Data Triple Estimates of Global Vulnerability to Sea-Level Rise and Coastal Flooding", in: Nature Communications 4844 (10/2019), p. 1-11.

Lagorio, Juan Jose: “U.N.'s Ban Says Global Warming Is 'an Emergency”, in: Reuters, 10.11.2007.

Lenton, Timothy M./Rockström, Johan/Gaffney, Owen et al.: "Climate Tipping Points. Too Risky to Bet Against”, in: Nature 575 (2019), p. 592-595.

Massaro, Thomas: Living Justice. Catholic Social Teaching in Action. Lanham, MD: Rowman \& Littlefield, ${ }^{3} 2016$.

McNeill, John R.: Something Under the Sun. An Environmental History of the Twentieth-Century World. New York, NY: W. W. Norton \& Company, 2000.

Mora, Camilo et al.: "Global Risk of Deadly Heat", in: Nature Climate Change 7 (2017), p. $5^{\mathrm{O}-5}-56$. 
Moyn, Samuel: Not Enough. Human Rights in an Unequal World. Cambridge: The Belknap Press of Harvard University Press, 2018.

Oreskes, Naomi: "Senate Hearing Prepared Statement", in: Hearing Before the Committee on Environment and Public Works United States Senate, o6.12.2006, https://www.govinfo.gov/content/pkg/CHRG-1ogshrg52324/html/CHRG109shrg52324.htm (date of last access: 13.03.2020).

Pachauri, Richard K./Meyer, Lawrence A. (ed.): IPCC: Climate Change 2014. Synthesis Report. Summary for Policy Makers. Contribution of Working Groups I, II and III to the Fifth Assessment Report of the Intergovernmental Panel on Climate Change. Geneva: IPCC, 2014.

Pontifical Council for Justice and Peace, Compendium of the Social Doctrine of the Church. Vatican City: Libreria Editrice Vaticana, 2005.

Quirico, Ottavo/Boumghar, Mouloud (ed.): Climate Change and Human Rights. An International and Comparative Law Perspective. London/New York, NY: Routledge, 2016.

Rignot, Eric: "Global Warming. It's a Point of no Return in West Antarctica. What Happens Next?”, in: The Guardian, 17.05.2014.

Ripple, William J./Wolf, Christopher/Newsome, Thomas M. et al. and $11.25^{8}$ Scientist Signatories from ${ }_{153}$ Countries: "World Scientists' Warning of a Climate Emergency", in: BioScience, 05.11.2019.

Rockström, Johan/Steffen, Will/Foley, Jonathan A. et al.: "A Safe Operating Space for Humanity", in: Nature 461 (2009), p. 472-475.

Rockström, Johan/Steffen, Will/Noone, Kevin et al.: "Planetary Boundaries. Exploring the Safe Operating Space for Humanity", in: Ecology and Society 14, (2/2009), art. 32.

Schellnhuber, Hans Joachim: "The MAD Challenge. Towards a Great Land-Use Transformation?", in: Plenary Session: “Climate Change. Global Risks, Challenges \& Decisions", 12.03.20o9. The talk is no longer available online (see report by Kanter, James: "Warming Could Cut Population to 1 Billion", in: New York Times, 13.03.20o9).

Schlenker, Wolfram/Roberts, Michael J.: "Nonlinear Temperature Effects Indicate Severe Damages to U.S. Crop Yields Under Climate Change", in: Proceedings of the National Academy of Sciences of the United States of America 106 (37/2009), p. 15594-15598.

Seager, Richard/Ting, Mingfang/Held, Isaac et al.: "Model Projections of an Imminent Transition to a More Arid Climate in Southwestern North America", in: Science 316 (5828/2007), p. 1181-1184.

Searles, Kaylin/Lathon, Erika: "Former Nashville Family Says St. John Residents Desperate after Irma, Pleads for Help", 2017, https://foxı7.com/news/local/formernashville-says-st-john-residents-desperate-after-irma-pleads-for-help (date of last access: 14.02 .2020$)$. 
Shelton, Dinah: "Developing Substantive Environmental Rights", in:Journal of Human Rights and the Environment (date of last access: 01.03.2010), p. 89-120.

Shepherd, Andrew/Ivins, Erik/Rignot, Eric et al.: "Mass Balance of the Antarctic Ice Sheet from 1992 to 2017", in: Nature 558 (2018), p. 219-222.

Shepherd, Andrew et al.: "Mass Balance of the Greenland Ice Sheet from 1992 to 2018 ", in: Nature (2019), p. 1-10.

Shue, Henry: Basic Rights. Subsistence, Affluence, and U.S. Foreign Policy. Princeton, NJ: Princeton University Press, 1980.

Steffen, Will/Richardson, Katherine/Rockström, Johan et al.: "Planetary Boundaries: Guiding Human Development on a Changing Planet”, in: Science 347 (6223/2015),

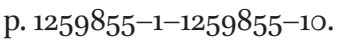

Steffen, Will/Rockström, Johan/Richardson, Katherine et al.: "Trajectories of the Earth System in the Anthropocene", in: Proceedings of the National Academy of Sciences of the United States of America 15 (33/2018), p. 8252-8259.

Tierney, Brian: The Idea of Natural Rights. Studies on Natural Rights, Natural Law, and Church Law. 1150-1625. Atlanta: Scholar's, 1997.

United Nations Department of Economic and Social Affairs: "World Population Projected to Reach 9.8 Billion in 2050, and 11.2 Billion in 2100", https://www.un.org/ development/desa/en/news/population/world-population-prospects-2017.html (date of last access: 02.05.2020).

United Nations General Assembly: Universal Declaration of Human Rights, 1948, https://undocs.org/A/RES/217(III) (date of last access: 13.03.2020).

UN-Water Decade Programme on Advocacy and Communication (UNW-D PAC): "The Human Right to Water and Sanitation. Milestones", https://www.un.org/water forlifedecade/human_right_to_water.shtml (date of last access: 12.01.2020).

Urban Climate Change Research Network (UCCRN): “The Future We Don't Want. How Climate Change Could Impact the World's Greatest Cities. UCCRN Technical Report", 2018, http://uccrn.org/the-future-we-dont-want/ (date of last access: 25.03.2020).

World Meteorological Organization: Proceedings of the World Climate Conference. A Conference of Experts on Climate and Mankind. Geneva: Secretariat of the World Meteorological Organization (WMO), 1979.

$\mathrm{Xu}$, Baiqing et al.: "Black Soot and the Survival of Tibetan Glaciers", in: Proceedings of the National Academy of Sciences of the United States of America 106 (2/2009), p. 22114-22118. 